\title{
VARIA
}

Richard Mackenzie-Gray Scott ${ }^{\star}$

r.scott@biicl.org

British Institute of International and Comparative Law

Charles Clore House

17 Russell Square

London WC1B 5JP, United Kingdom

\section{The European Union's Approach to Trade Restrictions on Cultural Property: A Trendsetter for the Protection of Cultural Property in Other Regions?}

\begin{abstract}
The protection of cultural property from illegal trade practices is an ongoing issue faced by the international community. In an attempt to combat the various problems at the local, domestic, regional and international levels, various organisation have taken steps to curb the illicit trade in cultural property through the implementation of trade restrictions. This article will assess the developments and shortcomings in this area, focusing on the legal frameworks part of the European Union, the Organization of American States and the African Union. The article provides a concise overview of the key initiatives in this area undertaken by these regional organisations and the broader international community, before concluding that the way forward in combating the illegal trade of cultural property is to learn from - and enhance - the methods employed by each respective organisation.
\end{abstract}

Keywords: cultural heritage law, cultural property, trade, Indigenous rights, international law

\footnotetext{
* Richard Mackenzie-Gray Scott is a Research Fellow at the British Institute of International and Comparative Law. The author is grateful for the research assistance of Paola lacovino and Jedsarit Sahussarungsi, Legal Interns, British Institute of International and Comparative Law. Thanks are also owed to Kristin Hausler for her valuable comments, in addition to the Journal's editorial team and the anonymous reviewers for their insights.
} 


\section{Introduction}

The illicit trafficking of cultural property has become an increasingly acknowledged international issue. This trade is one of the most extensive and profitable aspects of the international criminal community: it has been estimated that the value of such illegal cross-border transactions is between two to six billion USD per year. ${ }^{1}$ This is of concern for many reasons, most notably that profits from illicitly trafficked cultural goods directly fund terrorist organisations. ${ }^{2}$ There are also deeper-rooted problems within the ambit of cultural heritage law, in that affected persons of the international community can have their cultural rights severely impinged by such conduct. In response to such challenges many organisations have responded, in particular the United Nations Educational, Scientific and Cultural Organization (UNESCO), the United Nations Security Council (UNSC) and the European Union (EU). These organisations - among others - have implemented various legal measures to combat the illicit trade of cultural property. This article will focus on the developments within the EU framework that have addressed the issue of protecting cultural property from illicit trade and compare its progress with that of other regional bodies. Part 1 considers the development of the EU legal framework which is focused on cultural property, in particular the aspects of import restrictions and sanctions. This section will assess the extent of EU initiatives being taken on such matters. Part 2 will focus on the contemporary aspects of the Organization of American States (OAS) and the African Union (AU) aimed at addressing illicitly trafficked cultural property. This will provide an insight into how the EU compares with both organisations in the protection of cultural property. This regional-based approach will demonstrate which regional body is tackling the issue of illicit trade of cultural property in the most efficient manner. This makes it possible to offer, in Part 3 of this article, a proposition as to which regional model (if any) the international community should be looking toward in order to improve measures that assist in the prevention of illicit trade in cultural property. Before concluding, some thoughts are also offered concerning a standard to develop in order to ensure the effective protection of cultural rights. It is hoped that the outcome of this assessment will highlight the extent to which regional bodies are setting a benchmark for the wider international community in protecting cultural property from illicit trade, and ultimately whether these models are ones that should be followed by other organisations and states that are striving to improve the legal protections afforded to the cultural rights of individuals and communities around the world.

1 Figure from the year 2013, cited in G. Borgestede, Cultural Property, the Palermo Convention, and Transnational Organized Crime, "International Journal of Cultural Property" 2014, Vol. 21, p. 281.

2 ISIL and Antiquities Trafficking, "FBI News", 26 August 2015, https://www.fbi.gov/news/stories/2015/ august/isil-and-antiquities-trafficking [accessed: 21.11.2016]. For further analysis of the issues relating to terrorist organisations and cultural heritage vandalism see L.A. Amineddoleh, Cultural Heritage Vandalism and Looting: The Role of Terrorist Organizations, Public Institutions and Private Collectors, "Santander Art and Culture Law Review" 2015, Vol. 2, p. 27. 


\section{The EU's actions concerning trade restrictions and sanctions}

Being an economic union, the EU differs greatly from the OAS and AU. It is the only regional organisation in the world with a single market and common borders, which make the control of goods entering its geographical legal space more straightforward than in other regions. Thus, comparing any other regional organisation to the EU has intrinsic limits due to the EU's unique structure and function. It has many competences that allow it to regulate cultural goods from numerous angles, and the law and policy in this area has developed over a considerable period of time. ${ }^{3}$ The limitations on such comparisons also stem from the fact that the EU framework encompasses a thriving art market with a large number of prominent galleries and auction houses, which are regulated by EU law and policy. ${ }^{4}$ In fact it would be easier to compare the Council of Europe with the OAS and the AU. Nonetheless, the comparison in this article will help shed light on the way in which the three organisations share similarities, as well as how they combat illicit trade in cultural property, despite facing different obstacles.

Before discussing the EU legislation concerning sanctions and trade restrictions on cultural property, it is important to clarify what cultural goods fall within the scope of such protections. The property referred to in the context of the EU framework includes cultural works such as art, artefacts and historical objects. ${ }^{5}$ In this setting cultural goods should be understood as property that states - and the peoples of states - recognise as belonging to their cultural heritage. This understanding ties closely with the EU's concept of "national treasure" under Article 36 of the Treaty on the Functioning of the European Union (TFEU), which states:

The provisions of Articles 34 and 35 shall not preclude prohibitions or restrictions on imports, exports or goods in transit justified on grounds of public morality, public policy or public security; the protection of health and life of humans, animals or plants; the protection of national treasures possessing artistic, historic or archaeological value; or the protection of industrial and commercial property. Such prohibitions or restrictions shall not, however, constitute a means of arbitrary discrimination or a disguised restriction on trade between Member States. ${ }^{6}$

\footnotetext{
3 For the competence of the EU in cultural matters and its development, see the Treaty on the Functioning of the European Union, as amended by the Treaty of Lisbon (2007), Article 6(c); Review of the Balance of Competences between the United Kingdom and the European Union: Culture, Tourism and Sport, Foreign and Commonwealth Office, "HM Government", February 2014, https:/www.gov.uk/government/uploads/ system/uploads/attachment_data/file/279456/2901485_BoC_CultureTourismSport_acc.pdf [accessed: 21.11.2016].

4 See generally, A. Littoz-Monnet, The European Union and culture: Between Economic Regulation and European Cultural Policy, Manchester University Press, Manchester 2013.

5 M. Franco, A guide to the export and import of cultural goods between Russia and the European Union, "European Communities", June 2007, https://eeas.europa.eu/delegations/russia/documents/eu_russia/moving_art_07_en.pdf [accessed: 21.11.2016].

6 Consolidated version, OJ C 326, 26.10.2012, p. 47.
} 
The advances made with respect to trade restrictions on cultural property stem from this provision, which the EU has built upon to ensure the protection of cultural property from illicit trafficking. ${ }^{7}$ Through the development of the legal protections in this area, numerous factors that impact on the overall aim of preventing illicitly obtained cultural property from being traded within the EU single market have emerged. At the same time, the establishment of the free movement of goods within the EU creates a complex balance between ensuring such freedoms and protecting cultural property. One particular study notes that on a technical level, preventing illicit trade in cultural property includes "access to rapid, reliable information on the level of trafficking and the provenance of cultural goods [in addition to] raising awareness". ${ }^{8}$ The study goes on to explain that the stimulation or "aggravation" of illicit trade can arise from several factors: legal (such as the imbalances in domestic laws concerning cultural trafficking when states are compared with one another); operational (for example, the difficulty in obtaining relevant information); and political (that arise, for instance, in the event of armed conflict).?

As a response to these issues the EU has implemented various legal mechanisms under its competences. Within the geographical area of the EU the best examples of the measures taken by the EU in combating trafficked cultural property within the region can be seen through the lens of criminal law. In this context there is a link between Article 167 of the TFEU and the provisions enshrined in Title $\mathrm{V}^{10}$ Title V of the TFEU concerns freedom, security and justice within the EU framework. Article 87 under this title concerns the police forces of all Member States and cooperation between them in relation to the prevention, detection and investigation of criminal offences. ${ }^{11}$ With respect to the protection of cultural property from illicit trafficking, at first sight Title $V$ and Article 167 appear to be in harmony with one another. However, an issue that could potentially arise regarding the wording of Article 67, para. 1: "The Union shall constitute an area of freedom, security and

7 The past instruments, based on similar provisions, include: Council Regulation (EEC) No. 3911/92 of 9 December 1992 on the export of cultural goods (OJ L 395, 31.12.1992, p. 1), Council Directive 93/7/EEC of 15 March 1993 on the return of cultural objects unlawfully removed from the territory of a Member State (OJ L 74, 27.03.1993, p. 74; hereinafter: Council Directive 93/7/EEC). These instruments referred to the common provision Article 30 of the Treaty Establishing the European Community (consolidated version, OJ C 325, 24.12.2002, p. 33, now Article 36 TFEU).

8 Study on preventing and fighting illicit trafficking in cultural goods in the European Union, CECOJI-CNRS UMR 6224, Contract No. Home/2009/ISEC/PR/019-A2, Final Report - October 2011, p. 19, http://ec.europa.eu/home-affairs/doc_centre/crime/docs/Report\%20Trafficking\%20in\%20cultural\%20goods\%20 EN.pdf [accessed: 21.11.2016].

9 Ibidem, pp. 20-21.

10 Article 167, para. 1 reads: "The Union shall contribute to the flowering of the cultures of the Member States, while respecting their national and regional diversity and at the same time bringing the common cultural heritage to the fore."

11 Competent authorities in this area include the police, customs officials, and any other specialised law enforcement services. 
justice with respect for fundamental rights and the different legal systems and traditions of the Member States." The last phrase - "and the different legal systems and traditions of the Member States" - means that states can implement EU measures through their own means and interpretations. It must be recalled that the EU cannot implement statutes, and statutes are the basis of criminal responsibility at the domestic level. As noted above, with respect to the protection of cultural property from illicit trafficking within the EU, one of the key problems, from a legal point of view, is domestic law implementation. This approach to domestic criminalization of illegal trade in cultural property results in fragmentation, as there is an imbalance in the domestic legal protections between EU Member States. ${ }^{12}$ For example, within certain civil law jurisdictions, such as Italy and France, excavated cultural property automatically belongs to the state. However, in England and Wales the government does not automatically make a claim to such property. ${ }^{13}$ The Treasure Act (1996) provides that state expropriation of cultural property discovered by private entities is discretionary and is accompanied by compensation to the finder, owner, or occupier. ${ }^{14}$ This inevitably impacts what is legally deemed illicitly trafficked property, as it depends on where the property is found and what actor chooses to trade it. This is not a unique issue. States are ultimately the makers of their own laws, a power that can be limited in varying degrees depending on the status of other entities involved in a particular decision (for example, the EU, OAS or even the UNSC). At the international level, certain rules, for example those enshrined in treaties, may have one intended meaning at the outset, yet states' diverse interpretations of these provisions and their foothold in domestic laws can vary considerably from state to state. ${ }^{15}$ With that said, EU law is significantly different, in that the amount of leeway afforded to states implementing EU legislation is far more restrictive when compared to the implementation of international legal instruments.

Despite the potential differences in how EU Member States choose to tackle illicit trade in cultural property through their criminal laws, combatting such crimes from different perspectives is not necessarily problematic. Trafficking in cultural goods is a particularly serious type of crime against property, since it affects the cultural heritage of states, peoples and the heritage of humankind, meaning en-

12 See chapters in a book Handbook on the Law of Cultural Heritage and International Trade edited by J.A.R. Nafziger and R.K. Paterson (Edward Elgar, Chelthenham UK - Northampton MA USA 2014): M. Cornu, France, p. 126; K. Siehr, Germany, p. 160; E.N. Moustaira, Greece, p. 176; M. Frigo, Italy, p. 234; K. Chamberlain, K. Hausler, United Kingdom, p. 460.

13 For further insight into claims to excavated cultural property within England and Wales, see M. Wantuch-Thole, Cultural Property in Cross-Border Litigation, De Gruyter, Berlin 2015, pp. 275-324.

14 Treasure Act, 1996, Section 10(5) (consolidated version), http://www.legislation.gov.uk/ukpga/1996/24/ contents [accessed: 28.11.2018].

15 Examples include, but are not limited to, states divergent assertions on the laws applicable to the use of force in the context of self-defence, in addition to the concept of extraterritoriality in human rights law. 
forcing the law is paramount in safeguarding such priceless treasures - regardless of the different state methods for lawfully doing so. Furthermore, taking into consideration the nuanced approaches of states with respect to EU law, the platform allows for the illicit trafficking of cultural property to be combated from many angles. In addition, EU law offers a system that can harmonise domestic criminal law in this regard. Article 83 of the TFEU contains rules concerning the definition of criminal offences and sanctions. Para. 1 of this provision stipulates that in areas where there are particularly serious crimes with cross-border dimensions, sanctions can be utilised in order to combat such crimes on a common basis. ${ }^{16}$ Illegal trafficking in cultural property falls within this rule's ambit because of the nature of the offence - organised crime that involves cultural property - making it a common concern to all EU Member States. This means that so long as criminal networks are involved in the trafficking of cultural property, the crime falls within the jurisdiction of the EU. Combating this crime when it does not form part of a criminal organisation is also addressed through the functioning of the EU Parliament and Council. States' membership of the EU means transferring some of their powers to EU institutions in certain policy areas. This means that after approval from the Parliament, the Council can adopt a decision to list trafficking in cultural property as a serious crime with cross-border aspects. ${ }^{17}$ The second paragraph of Article 83 explicitly mentions harmonisation, ${ }^{18}$ meaning it can be utilised as a legal avenue through directives establishing minimum rules regarding the definition of offences, and sanctions with respect to illicit trade in cultural property. An example of this process is Directive 2014/60/EU on the return of cultural objects unlawfully removed from

16 See TFEU, Article 83, para. 1:

"The European Parliament and the Council may, by means of directives adopted in accordance with the ordinary legislative procedure, establish minimum rules concerning the definition of criminal offences and sanctions in the areas of particularly serious crime with a cross-border dimension resulting from the nature or impact of such offences or from a special need to combat them on a common basis.

These areas of crime are the following: terrorism, trafficking in human beings and sexual exploitation of women and children, illicit drug trafficking, illicit arms trafficking, money laundering, corruption, counterfeiting of means of payment, computer crime and organised crime.

On the basis of developments in crime, the Council may adopt a decision identifying other areas of crime that meet the criteria specified in this paragraph. It shall act unanimously after obtaining the consent of the European Parliament."

17 Supranational Decision-Making Procedures, EU Parliament, "Fact Sheets on the European Union", 2016 , http://www.europarl.europa.eu/ftu/pdf/en/FTU_1.4.1.pdf [accessed: 21.11.2016]. See also S. Peers, Guide to EU decision-making and justice and home affairs after the Treaty of Lisbon, "Statewatch", December 2010, http://www.statewatch.org/analyses/no-115-lisbon-treaty-decision-making.pdf [accessed: 21.11.2016]. 18 "If the approximation of criminal laws and regulations of the Member States proves essential to ensure the effective implementation of a Union policy in an area which has been subject to harmonisation measures, directives may establish minimum rules with regard to the definition of criminal offences and sanctions in the area concerned. Such directives shall be adopted by the same ordinary or special legislative procedure as was followed for the adoption of the harmonisation measures in question, without prejudice to Article 76." 
the territory of a Member State. ${ }^{19}$ The EU framework within the ambit of criminal law that can be applied to cases of trafficking in cultural property is extensive. ${ }^{20}$ This allows the complexity of each individual case to be appropriately addressed on its individual merits, by providing functional laws that effectively engage with (often complex) factual realities. In dealing with illicitly trafficked cultural property coming from outside of the EU, the Syrian situation can be used as an illustrative example of how the EU has acted externally in order to prevent such occurrences. ${ }^{21}$ This is not the first time that such an initiative has been taken: in 2003 the EU also assisted in Iraq regarding the same type of cultural property protection issues. ${ }^{22}$ The EU's reaction to the destruction and looting of cultural property in places such as Syria has also bolstered the international response to combatting such crimes. In 2013 the European Commission implemented a decision to assist the Syrian population and host communities in Jordan through special measures. ${ }^{23}$ The Decision stipulates that one of the key components of assisting the Syrian population and surrounding communities in coping with the crisis in Syria, in addition to allowing it to prepare for a swift recovery, is by safeguarding Syrian cultural property. ${ }^{24}$ The action taken in this area is undertaken by utilising the resources and collaborating between the EU, UNESCO, the International Centre for the Study of the Preservation and Restoration of Cultural Property (ICCROM) and the International Crim-

19 Directive 2014/60/EU of the European Parliament and of the Council of 15 May 2014 on the return of cultural objects unlawfully removed from the territory of a Member State and amending Regulation (EU) No. 1024/2012 [Recast], OJ L 159, 28.05.2014, p. 1. This Directive repeals Council Directive 93/7/EEC, with effect from 19 December 2015.

20 Further provisions of the TFEU, such as Article 82, para. 2 (the harmonisation of domestic procedural rules: rights of the victim, individual rights during proceedings and admissibility of evidence), and Articles 85,87 and 88 , reinforce collaboration in data collection, arrest and prosecution between the bodies that make up the EU and the Member States - both with each other and the EU. There are also a number of other legal instruments applicable in the EU that bolster the TFEU framework in this regard: United Nations Convention against Transnational Organized Crime, 15 November 2000, 2237 UNTS 319; European Convention on Mutual Assistance in Criminal Matters, 20 April 1959, 472 UNTS 185; First Additional Protocol to the European Convention on Mutual Assistance in Criminal Matters, 13 March 1978, ETS No. 099; Second Additional Protocol to the European Convention on Mutual Assistance in Criminal Matters, 8 November 2001, ETS No. 182; Council Framework Decision 2001/500/JHA of 26 June 2001 on money laundering, the identification, tracing, freezing, seizing and confiscation of instrumentalities and the proceeds of crime, OJ L 182, 5.07.2001, p. 1.

21 It is also by no means unique. There are many other states and communities that fall victim to this practice. Others include, but are not limited to, Afghanistan, Azerbaijan, Belize, Iran, Iraq, Nigeria, Turkey and Yemen.

22 Council Regulation (EC) No. 1210/2003 of 7 July 2003 concerning certain specific restrictions on economic and financial relations with Iraq and repealing Regulation (EC) No. 2465/96, OJ L 169, 8.07.2003, p. 6.

23 Commission Implementing Decision on 2013 Special Measure for the Syrian population and host communities in Jordan, C 6795, European Commission, Brussels, 10 October 2013, http://ec.europa.eu/enlargement/ neighbourhood/pdf/key-documents/syria-jordan_sm_2013_merged-financing-decision-and-action-fiches_en.pdf [accessed: 21.11.2016].

24 Ibidem, Annex I, p. 12. 
inal Police Organisation (INTERPOL). ${ }^{25}$ One of the key aims of this action plan is to improve capacities at the national, regional and international levels to prevent illicit trafficking in cultural property in Syria and neighbouring states. ${ }^{26}$ The EU has also heavily financed this initiative and raised awareness with respect to the importance of Syrian cultural heritage, in addition to enabling preventative measures to be executed that will help safeguard Syrian cultural heritage. ${ }^{27} \mathrm{It}$ is clear that the EU's approach to protecting cultural property from illicit trafficking is secondary to the more immediate human-related impacts of the ongoing conflict in Syria, yet it is beyond dispute that in the opinion of the $\mathrm{EU}$, the protection of cultural property that has been looted from Syrian museums and archaeological sites must be protected from illicit trade practices; evidence of this is provided by the EU Council Regulation of 2013 concerning the Syrian situation. ${ }^{28}$ The instrument clearly states the importance of returning goods of Syrian heritage to their "legitimate owners" by prohibiting the import, export or transfer of such goods. ${ }^{29}$ In amending Regulation (EU) No. 36/2012, ${ }^{30}$ the following rule was inserted:

It shall be prohibited to import, export, transfer, or provide brokering services related to the import, export or transfer of, Syrian cultural property goods and other goods of archaeological, historical, cultural, rare scientific or religious importance, including those listed in Annex XI, where there are reasonable grounds to suspect that the goods have been removed from Syria without the consent of their legitimate owner or have been removed in breach of Syrian law or international law, in particular if the goods form an integral part of either the public collections listed in the inventories of the conservation collections of Syrian museums, archives or libraries, or the inventories of Syrian religious institutions. ${ }^{31}$

The creation of this rule constitutes an important step in augmenting the fight against illegal trade in cultural property. Nonetheless, the EU has a hard road ahead of it to help prevent the illicit trafficking of cultural property originating in Syria, which is not helped by the acknowledged problem of inadequate documentation of antiquities in the state. ${ }^{32}$ This issue may be compounded by the concept of auto-

${ }_{25}$ ICCROM is an intergovernmental organisation dedicated to the preservation of cultural heritage worldwide through training, information, research, cooperation and advocacy programmes.

26 Commission Implementing Decision...

27 Ibidem. The EU has contributed around 5.5 million EUR on this one initiative alone (see pp. 14-15). Furthermore, up until 10 October 2013 the EU has contributed 1.2 billion EUR in response to helping address the Syrian crisis (see p. 6).

28 Council Regulation (EU) No. 1332/2013 of 13 December 2013 amending Regulation (EU) No. 36/2012 concerning restrictive measures in view of the situation in Syria, OJ L 335, 14.12.2013, p. 3.

29 Ibidem. Preamble, para. 3.

30 Council Regulation (EU) No. 36/2012 of 18 January 2012 concerning restrictive measures in view of the situation in Syria and repealing Regulation (EU) No. 442/2011, OJ L 16, 19.01.2012, p. 1.

31 Council Regulation (EU) No. 1332/2013, Article 1, para. 4 (Article 11c).

32 Commission Implementing Decision..., p. 5. 
matic state ownership in Syria. Under Article 4 of the Antiquities Law "All movable and immovable antiquities, and antiquities placed in the Syrian Arab Republic are considered public properties of the State." 33 The implications of this legal position are hard to unpack considering the severity of the crimes that are being perpetrated in Syria against cultural property. Syria's cultural heritage is being destroyed in spite of legal protections, regardless of their theoretical reach and capacity. At present, the capability of Syrian domestic law is not the major problem; the more pressing issue relating to cultural property protection is to prevent such goods from being destroyed, looted and trafficked in the first place. It is a stereotypical (and unfortunately widespread) reaction in "developed" states around the world to criticise shortcomings in "developing" states' domestic legislation, instead of focussing attention on initiatives that address more immediate concerns. Furthermore, attempting to assess the suitability of a domestic legal framework in a particular sector during such a volatile period results in inaccuracies. With respect to cultural heritage protection in Syria, the international community should be looking towards ending such criminal conduct and assisting in providing a platform for stability, which is precisely the manner in which the EU is tackling this issue at present. The time will come for examining the potential gaps in Syrian domestic law with respect to the protection of cultural heritage. However, at present it would be ignorant to assume that Syria is in a stable enough condition to undertake legitimate policy change in any area of law.

Despite the multiple barriers to the protection of Syrian cultural property faced by the international community, the EU is spearheading practical avenues, such as establishing a "geo-referenced (GIS) national database" of all Syrian cultural sites and monuments in order to consolidate reliable information to be utilised by the authorities concerned. ${ }^{34}$ The key factor in this process is collaboration across all levels. The next step that the EU has taken, with such solidarity in mind, is to set up various cultural information-sharing networks and databases regarding stolen property. ${ }^{35}$ In order to utilise these advances most effectively, border police, customs officials and museum curators are all being given extensive training on specific pieces of cultural property, so that stolen artefacts can be detected. ${ }^{36}$

Syrian cultural property forms part of the state's rich cultural heritage and diversity, which also contributes to the common heritage of humankind. Syrian cultural property also forms part of an extremely important symbol for Syrian peoples' identity (as with all cultural property native to any state), which provides a platform

\footnotetext{
33 Antiquities Law passed under Decree, Law No. 222 of 26 October 1963, http://portal.unesco.org/culture/fr/files/30606/11438206173Antiquities_Law.pdf/Antiquities\%2BLaw.pdf [accessed: 28.11.2016], Article 4.

34 Commission Implementing Decision..., p. 13.

35 Ibidem.

36 Ibidem, pp. 12-13.
} 
for cultural integration and unity within the state. In monetary terms, Syrian heritage is a major asset for the state's economy through the tourism industry. Prior to the initiation of the armed conflict, tourism was a growing sector that accounted for $12 \%$ of Syrian national income, in addition to generating more employment. ${ }^{37}$ The importance of protecting the Syrian people and Syrian heritage is of the upmost importance, and has been viewed as an issue that threatens international peace and security. ${ }^{38}$ The EU is playing a pivotal role preventing Syrian cultural property from being illegally traded, by lowering the possibility of it being imported, not only into the EU, but into states neighbouring Syria. Its financial contributions and logistic support to a state outside of the European community of states provides a benchmark for positive, outward-looking advancements in this field.

It is clear that illicit trafficking in cultural property is (rightly) treated with utmost importance at the policy level within the EU. This is evident from the measures being implemented outside of the EU's geographical area. Furthermore, the sophisticated legal framework provided by the TFEU, in combination with the powers of the Parliament and Council, greatly assist Member States in tackling unlawful cultural trade practices. As one commentator has noted, the prevention of, and fight against, illicit trafficking of cultural property by the EU has not only constituted a prominent topic of public discourse, but also an issue that the EU has been actively (and successfully) combating for years. ${ }^{39}$

\section{The approach of the OAS and AU}

The prominence afforded to the protection of cultural property and cultural heritage is imbedded within the framework of the AU. ${ }^{40}$ The OAS has also made a strong commitment to the protection of cultural property through both binding and non-binding means. This section will first address the framework of the OAS in protecting cultural property from illicit trafficking, and then examine the mechanisms utilised by the AU. In this way I hope to provide a comparison of the two systems, which will also highlight in what ways the two organisations can learn from the EU, and vice versa.

37 A. Baker, M. Anjar, Syria's Looted Past: How Ancient Artifacts Are Being Traded for Guns, "Time Magazine", 12 September 2012, http://world.time.com/2012/09/12/syrias-looted-past-how-ancient-artifacts-are-being-traded-for-guns/\#ixzz26ujLHJ8C [accessed: 21.11.2016].

38 United Nations Security Council Resolution No. 2199 (12 February 2015) UN Doc. S/RES/2199, in particular paras. 15-17.

39 M. Cornu, Recasting restitution: interactions between EU and international law, "Uniform Law Review" 2015, Vol. 20, p. 637, pp. 639-640.

40 Cultural rights and heritage are mentioned throughout the African Charter on Human and Peoples' Rights (27 June 1981, 1520 UNTS 217) (African Charter). See also the Charter for African Cultural Renaissance (adopted by the Sixth Ordinary Session of the Assembly, held in Khartoum, Sudan, 24 January 2006). 
The primary OAS treaty for the protection of cultural property is the Convention of San Salvador. ${ }^{41}$ To this date, the Convention has been ratified by thirteen states of the OAS ${ }^{42}$ With respect to combating illicit trafficking in cultural property, there are numerous provisions within the treaty that are of great value. In an explicit reference to combating unlawful trade in cultural property, Article 7 reads:

Regulations on ownership of cultural property and its transfer within the territory of each state shall be governed by domestic legislation. With a view to preventing unlawful trade in such goods, the following measures shall be encouraged:

a) Registration of collections and of transfer of cultural property subject to protection;

b) Registration of transactions carried out by establishments engaged in the sale and purchase of such property;

c) Prohibition of imports of cultural property from other states without appropriate certificate and authorization. ${ }^{43}$

However Article 7 does not impose a binding obligation on state parties to implement laws related to the three encouraged measures. Member States of the OAS have the discretion over how, or if, they implement rules addressing these actions. Nevertheless, when taking into account the object and purpose of this treaty, the guidelines under Article 7 become more persuasive for states than may seem when reading the provision alone (outside its overall context). The second line of the preamble contains a declaration of the OAS's concern over the "continuous looting and plundering of the native cultural heritage suffered by the countries of the hemisphere, particularly the Latin American countries". ${ }^{44}$ Article 1 goes on to state:

The purpose of this Convention is to identify, register, protect, and safeguard the property making up the cultural heritage of the American nations in order: (a) to prevent illegal exportation or importation of cultural property; and (b) to promote cooperation among the American states for mutual awareness and appreciation of their cultural property. ${ }^{45}$

Articles 3, 11, and 12 of the Convention of San Salvador should also be consulted to emphasise the aims of protecting and retrieving cultural property in the face of theft and illegal trade. The purpose of the treaty is to set out steps to identify stolen cultural property and set up an international registry of protected items, thereby providing a platform where information that protects cultural goods

41 Convention on the Protection of the Archaeological, Historical, and Artistic Heritage of the American Nations, 16 June 1976, UNEP/GC.15/Int.2, p. 150.

42 General information on the treaty is available on the OAS website at: http://www.oas.org/juridico/english/sigs/c-16.html [accessed: 21.11.2016].

43 Convention of San Salvador, Article 7.

44 Ibidem, Preamble.

45 Ibidem, Article 1. 
against illicit trade practices can be shared. Another important aspect of this treaty is the consideration (appropriately) given toward indigenous peoples and communities. Blake has understood the wording of Article 2, para. (a) ${ }^{46}$ to mean that an "exclusive emphasis [is] placed on indigenous forms of cultural heritage". ${ }^{47}$ This position is reinforced if one looks at the history of the San Salvador Convention and the steps taken by the OAS in the late $1980 \mathrm{~s} .{ }^{48}$ Allowing for cultural property to be returned to its rightful place of origin is an issue that transcends the "traditional", state-centric approach to international law and policy. The OAS should be commended for its approach to protecting cultural property from illicit trafficking, which helps ensure that the concerns of indigenous communities are taken into consideration as part of the process. In creating a special internationally-binding treaty focusing on such a niche area of law - the protection of cultural property from illicit trade - in addition to continuously developing the relative strength of cultural initiatives undertaken ${ }^{49}$ the OAS has created a specific framework wherein Member States are more likely to harmonise their own laws with the standards set at the regional level. Indeed, this contention even holds true with respect to states that have not yet ratified the San Salvador Convention. ${ }^{50}$

46 "Article 2.

The cultural property referred to in the preceding article is that included in the following categories:

a) Monuments, objects, fragments of ruined buildings, and archaeological materials belonging to American cultures existing prior to contact with European culture, as well as remains of human beings, fauna, and flora related to such cultures."

47 J. Blake, International Cultural Heritage Law, Oxford University Press, Oxford 2015, p. 321.

48 During this time the General Assembly of the OAS requested that the Inter-American Commission on Human Rights prepare a legal instrument on indigenous peoples' rights, which resulted in the creation of the Draft Declaration on the Rights of Indigenous Peoples being approved by the Commission in 1997 (IACHR, 26 February 1997, 133 ${ }^{\text {rd }}$ session, $95^{\text {th }}$ Regular Session).

49 For an overview of the OAS and its work relating to cultural heritage, see L. Lixinski, Intangible Cultural Heritage in International Law, Oxford University Press, Oxford 2013, pp. 68-76; See also the Organisation's more recent work in the Caribbean: http://caribheritage.org/project [accessed: 21.11.2016].

50 For example the US has not signed the Convention, yet domestically it has protected cultural property by its own domestic laws. See the Cultural Property Implementation Act (CPIA) 19 USC, (1983), Publ. L. No. 97-466, 96 Stat. 2329, current version at 19 USC para. 2601-2613 (2006), which implemented the 1970 UNESCO Convention in the United States. According to para. 2607 of the CPIA, the import of stolen cultural objects documented as a part of the inventory of a museum or other public institution located in another nation which had signed the 1970 UNESCO Convention is prohibited. Para. 2609 of the Act regulates the civil remedies of seizure or forfeiture of cultural property to be carried out by customs officers. Other US domestic laws unrelated to international law complete the US regime of the protection of cultural property. These rules often deal with claims promoted by foreign governments in order to obtain the return of undiscovered or unexcavated objects which can be considered to fall under state ownership according to their national laws. In this regard, the National Stolen Property Act (NSPA) 18 USC paras. 2314-2315 can be applied, which prohibits "the knowing transfer or transport in interstate or international commerce of stolen property". Finally, the US controls illicit trafficking of cultural property through the Native American Graves Protection and Repatriation Act (NAGPRA), 25 USC paras. $3301 \mathrm{ff}$., which prevents the US from engaging in illicit transfers of objects belonging to indigenous communities. See also G. Strother, Resolving Cultural Property Disputes in the Shadow of the Law, "Harvard Negotiation Law Review" 2014, Vol. 19, p. 335, pp. 343-346. Furthermore, while Canada has not ratified the Convention, illicit trafficking is addressed in 
Moving on to the AU framework, it must be noted that African states, and by association the $\mathrm{AU}$, face the issue of recovering from European colonial occupation. Therefore, African states are exceptionally vulnerable to trafficking in cultural property, not only that which is part of their own heritage, but also that belonging to states and communities located outside of the continent. ${ }^{51}$ This drawback is also shared by American states - highlighting a common problem faced by both the OAS and AU. However, by an examination of various policy reports and academic commentaries, it cannot be affirmed that the AU has carried out concerted action in order to tackle the illicit trading of objects belonging to AU states' cultural heritage. ${ }^{52}$ In 2006 the AU did issue the Charter for African Cultural Renaissance, which establishes (in Articles 26 and 27) the duty of African states to "take steps to put an end to the pillage and illicit traffic of African cultural property". ${ }^{53}$ Despite the progressive policy behind this instrument and its potential to improve the framework for the protection of cultural property within the AU, it has been criticized for addressing very specific issues in a blanket manner. ${ }^{54}$ However, this focus on mutual cooperation between states within the $\mathrm{AU}$ should not be so swiftly dismissed as falling short of protecting cultural property from illicit trade. It could be posited that the mere fact that this instrument is more recent than its European and American counterparts makes it more progressive in nature.

There are signs of $A U$ influence that can be inferred from examining different programmes regarding the monitoring and control of cultural property leaving its state of origin. For example, Nigeria has relied on the joint actions of UNESCO, the International Council of Museums, and INTERPOL. In 1987 UNESCO reported that nine cultural objects had been stolen from the Nigerian Jos National Museum, which contributed to their identification and subsequent return from an auction house in Switzerland..$^{55}$ Nigeria's own contribution to this positive outcome was

the Cultural Property Import and Export Act, R.S.C. 1985, c. C-51, which implemented the 1970 UNESCO Convention on the Means of Prohibiting and Preventing the Illicit Import, Export and Transfer of Ownership of Cultural Property (14 November 1970, 823 UNTS 231; hereinafter: 1970 UNESCO Convention), preventing the export and import in Canada of objects banned or controlled by their state of origin.

51 F. Shyllon, The Recovery of Cultural Objects by African states through the UNESCO and UNIDROIT Conventions and the Role of Arbitration, "Uniform Law Review" 2000, Vol. 5, p. 219; F. Shyllon, The Nigerian and African Experience on Looting and Trafficking in Cultural Objects, in: B. T. Hoffman (ed.), Art and Cultural Heritage: Law Policy and Practice, Cambridge University Press, Cambridge 2006, p. 137.

52 The following report summarises the lack of action taken by the African states as a collective: F. Shylon, V. Négri, M. Schneider, The Role of National and International Legal Instruments in the Protection of African Cultural Goods, "Report prepared for the second Pan-African Cultural Congress: Inventory, Protection and Promotion of African Cultural Goods", 5-7 October 2009, http://portal.unesco. org/en/files/48670/13173105361role_of_national_and_intl_leg_instrs.pdf/role\%2Bof\%2Bnational\%2Band\%2Bintl\%2Bleg\%2Binstrs.pdf [accessed: 21.11.2016].

53 Charter for African Cultural Renaissance (adopted by the Sixth Ordinary Session of the Assembly, held in Khartoum, Sudan, 24 January 2006), Article 26.

54 V. Vadi, B. De Witte, Culture and International Economic Law, Routledge, London 2015, p. 138.

55 F. Shyllon, The Recovery..., p. 219, p. 224. 
twofold. Firstly, Decree 77 of 1979 established a National Commission for Museums and Monuments, which took the step of declaring antiques of the state as national monuments. ${ }^{56}$ This allowed such property to be monitored more closely; meaning only accredited agents in Nigeria could legally buy or sell cultural property. Secondly, Nigeria has created a Committee on the Looting of Nigeria's Cultural Property. This entity has the charge of controlling the trade of cultural property to ensure that no illegally obtained goods can be traded on the market. ${ }^{57}$ Unfortunately, these provisions and rules have not been as effective as hoped in tackling the exportation of illegally obtained Nigerian heritage objects; many Nigerian artefacts have been found to be in circulation in the European art market. ${ }^{58}$ The example of Nigeria represents an African state that is taking steps to tackle the illicit trade in cultural property through trade restrictions that could be greatly improved with greater action being taken at the regional level through the AU.

Another state within Africa that has attempted to improve the protection of cultural property through trade restrictions is Mali. Within the framework of its controls on the import and export of cultural objects carried out in light of the 1970 UNESCO Convention, Mali is the only African state affected by the Convention indirectly. This is owing to the US implementation of the UNESCO convention through the Cultural Property Implementation Act. ${ }^{59}$ This Act allows the US to enter into bilateral agreements pursuant to the UNESCO Convention in order to apply restrictions on the import of cultural objects coming from states that request cooperation with the US in this field. Mali is the only African state that has entered into such an agreement so far. At the time of this development there was a large amount of pillaging being undertaken in an archeological site near the Niger River Valley, which may have prompted Mali's action in this area. ${ }^{60}$ Indeed, Mali adopted legislation protecting cultural (and natural) heritage, including further rules restricting trade in cultural goods. ${ }^{61}$ However, there appears to be a lack of interest

5628 September 1979, https://committeeforculturalpolicy.org/wp-content/uploads/2014/06/Decree-n\%C2\%B0-77.pdf [accessed: 28.11.2016]. O.A. Akinade, Illicit Traffic in Cultural Property in Nigeria: Aftermaths and Antidotes, "African Study Monographs" 1999, Vol. 20, p. 99, p. 105.

57 Ibidem, p. 104.

58 W. Parry, Ancient Statues Smuggled from Nigeria Being Returned Home, "NBC News", 26 July 2012, http:// www.nbcnews.com/id/48346178/ns/technology_and_science-science/t/ancient-statues-smuggled-nigeria-being-returned-home/\#.VzsQ1PkrKUk [accessed: 21.11.2016].

59 Cultural Property Implementation Act (CPIA) 19 USC, (1983), Publ. L. No. 97-466, 96 Stat. 2329, current version at 19 USC para. 2601-2613 (2006). The section dedicated to bilateral agreements engaged with the "requesting states" is para. 2602.

60 ICOM, Red List: Niger Valley (Mali): http://archives.icom.museum/redlist/afrique/english/page04.htm [accessed: 21.11.2016].

61 Looting, the subsistence digging economy in Mali; and stemming the flow of looted antiquities from Mali to the USA, "Conflict Antiquities", 3 April 2012, https://conflictantiquities.wordpress.com/2012/04/03/mali-looting-export-usa-import/ [accessed: 21.11.2016]. 
by African states and the $\mathrm{AU}$ towards amending national legislation in the light of principles established by international conventions on the illicit trafficking of cultural property. ${ }^{62}$

At present, at least for the time being, there appears to be a minimal amount of action being carried out by the $\mathrm{AU}$ in dealing with the illicit trade of cultural property. In essence the $\mathrm{AU}$ appears to be leaving a large amount of action on this issue in the hands of states. If this method is to yield positive outcomes in preventing cultural property from being illegally traded, a way forward is to continue fostering an environment wherein African states can enter into agreements with external states (or other regional organizations), such as in the case of Mali. ${ }^{63}$ Having said that, African states could greatly benefit from becoming parties to the 1970 UNESCO Convention; as yet only thirty African states have ratified it. ${ }^{64}$ Moreover, it is clear that the AU needs to develop its own policy and legal framework on protecting cultural property, in particular through trade restrictions and monitoring. For the time being, it is individual states that are taking initiatives within Africa in order to protect their heritage. These states are paving the way for new ideas that could be taken up by the AU, in essence functioning as an inverse of the EU system, where reciprocal action bolsters the protection afforded to cultural property. While these national examples may seem out of place in an article focusing on regional comparisons, they serve as a positive example that individual states within Africa possess the capability of improving their laws and policies on protecting cultural property from illicit trade practices, in spite of the fact that there is severely limited regional guidance on the matter. ${ }^{65}$

\section{The EU model as a benchmark international standard?}

As with all issues that have an international component, it is this author's view that internal, inward-looking measures aimed at improving situations within a state or region do not help situations (neither in the short nor long-term) nearly as much as collaborative, outward-looking diplomacy. Based on this logic, several assumptions can be drawn from the approaches of the EU, OAS and AU in protecting cultural property from illicit trade practices through laws and policies concerning trade restrictions.

62 It has been proposed that the next useful step towards more effective protections could be the harmonization of laws and joint border patrols throughout the AU, following the example of the Commonwealth scheme. See F. Shyllon, The Recovery..., p. 219, pp. 224-238.

63 Another example in this regard is Recommendation 1651 (2004) on Ending the Plundering on African cultural objects of the Parliamentary Assembly of the Council of Europe: https://assembly.coe.int/nw/xml/ XRef/Xref-XML2HTML-en.asp?fileid=17196\&lang=en [accessed: 21.11.2016].

64 Information on the Convention can be accessed at: http://www.unesco.org/eri/la/convention.as$\mathrm{p}$ ?KO=13039\&language $=\mathrm{E} \&$ order=alpha [accessed: 21.11 .2016 ].

65 There are many states outside of Africa that have undertaken initiatives similar to those adopted by Mali and Nigeria. However, they have been able to do so in part by benefiting from being empowered by, and connected with, regional environments that are more advanced in the area of cultural property protection. 
The obvious advantage that the EU has over the other two organisations is its legal competence, and the fact that it is an organisation with an integrated economic market. Within the EU, Member States must implement directives and regulations concerning the protection of cultural property within a certain timeframe. The distinction between the two legislative acts is that regulations must be applied in their entirety across the EU, whereas a directive sets out a common EU goal that Member States must achieve within a specific time frame. ${ }^{66}$ Directives allow Member States more autonomy to devise their own laws on how to reach a directive's goals, while regulations are more prescriptive in their application. In certain instances this means that domestic legislation in EU Member States may differ in their language and/or interpret EU provisions in different ways ${ }^{67}$ However, there is an overriding element of solidarity in this context that allows cultural property to be more effectively protected from illicit trade, because Member States' own laws and policies on this issue are grounded in the EU's initiatives. ${ }^{68}$ This allows such an issue to be addressed from a variety of approaches, thereby improving the scope of protection within the EU as a whole. The OAS has a similar framework, which sets the benchmark standard for states while allowing states more discretion in how, or if, they choose to implement policy choices of the OAS. ${ }^{69}$ The EU framework allows it to go a step further than the OAS. However, the OAS has created the specific San Salvador Convention that addresses the illicit trafficking of cultural property. This creates the same binding obligations on states as the directives and regulations of the EU, albeit in a less mandatory form, as OAS Member States still have to ratify the treaty and accept to be bound by its contents. The AU's legal competence is far less extensive than the EU's or OAS's. The protection of cultural property against illicit trafficking is only marginally addressed at a policy level within the ambit of the $\mathrm{AU}$, and concrete legal protections at a regional level are severely lacking. This aspect of the fight against illegal trade in cultural property is left purely to the discretion of African states - although this circumstance has the potential to not be too problematic (which will be discussed below). Unfortunately, the minimal amount of $\mathrm{AU}$ focus on this issue prevents African states from being guided towards implementing their own sustainable and collaborative initiatives that could benefit larger regions within Africa.

66 P. Craig, G. de Burca, EU Law: Text, Cases, and Materials, $6^{\text {th }}$ edn. Oxford University Press, Oxford 2015; K.-D. Borchardt, The ABC of European Union Law, Publications Office of the European Union, Luxembourg 2010, p. 88, https://eeas.europa.eu/sites/eeas/files/15102015eu_law.pdf [accessed: 21.11.2016].

67 K.D. Borchardt, op. cit.

68 For further insights on this topic, see D. Obradovic, N. Lavranos (eds.), Interface Between EU Law and National Law: Proceedings of the Annual Colloquium of the G.K. Van Hogendorp Centre for European Constitutional Studies, Europa Law Publishing, Groningen 2007.

69 For further information on the functioning of the OAS's legal framework in the context of cultural rights, see K. Hausler, Collective Cultural Rights in the Inter-American Human Rights System, in: A. Jakubowski (ed.), Cultural Rights as Collective Rights: An International Law Perspective, Brill-Nijhoff, Leiden - Boston 2016, p. 222. 
The second element that should be taken into consideration is the scope and flexibility each organisation has in terms of its capacity to protect cultural property. Once again the EU stands out in this regard due to the functional nature of its legal framework. The way in which EU declarations and regulations function allows regional policy to be implemented into binding law incredibly quickly. These two measures can be adopted on any EU law issue, giving the EU flexibility to engage with factual realities at the time. The elasticity afforded by such a unique legal framework, which boosts the capacity to narrow or widen the scope of a particular legal protection, puts the EU is in an excellent position to react swiftly and appropriately to challenges faced by the global community concerning illicit trade in cultural property. The OAS is not limited with respect to legislative flexibility, but lacks the speed of the EU system. The organisation can create treaties on specific areas of policy concern, which allows the content to be somewhat flexible and tailored in scope, yet such treaties have to appeal to the interests of states in order to persuade them into ratifying, whereas the EU has extensive autonomy in applying new rules within the Member States. The treaties of the OAS are not directly applicable to Member States, whereas a regulation or directive of the EU is applicable to all Member States. It is unclear whether the AU system can offer the benefit of legislative flexibility in tackling the illicit trade of cultural property, due to the lack of current law and policy produced by the Organisation. The African Charter does mention cultural rights and the protection of cultural heritage, but there is no reference to the protection of cultural property. In short, the AU system regarding the protection of cultural property is in need of specificity and further development.

With respect to the precise substantive content of the legal provisions provided to protect cultural property from illicit trade, the OAS is more advanced than either the EU or the AU. This is because of the prominence afforded to indigenous peoples and communities in protecting their cultural property. It should be noted that at the European level there are fewer indigenous communities and people within the geographical space of the EU compared with those within the OAS and AU. ${ }^{70}$ Nonetheless, "indigenous rights issues are rapidly emerging as a European issue in general and as a European Union concern in particular". ${ }^{71}$ Furthermore, the issue of indigenous rights has been afforded substantial attention within the EU framework, ${ }^{72}$ highlighting the fact that there may be regional instruments created in the future that focus on indigenous cultural property. Indeed, the notion that the limited number of indigenous communities in Europe provides an argu-

70 J. Beqiraj, Indigenous Peoples' Cultural Identity under EU Law and the ECHR: A Non-trade Interest or a Human Right?, in: F. Ippolito, S.I. Sanchez (eds.), Protecting Vulnerable Groups: The European Human Rights Framework, Hart, Oxford 2015, p. 159, p. 161.

71 Ibidem, pp. 160-161.

72 Ibidem, pp. 170-178. See also Working Document of the Commission of May 1998 on support for indigenous peoples in the development co-operation of the Community and the Member States: https://eeas. europa.eu/human_rights/ip/docs/working_doc_98_en.pdf [accessed: 21.11.2016]. 
ment against advancing the legal framework in this area through the creation of a new regionally enforceable instrument focusing on cultural property protection, is the equivalent to arguing that it isn't necessary to have international legal instruments regarding refugees because there are only a small number of refugees in the world when compared to non-refugees. ${ }^{73}$ On the contrary, the smaller the number of a particular group in existence within a specific area warrants additional advocacy on their behalf and tailored development. The concept of minority rights exists to protect underrepresented individuals, groups and communities, including serving as a basis to enhancing their quieter voice - owing to their comparatively smaller numbers - with respect to political claims. ${ }^{74}$ Throughout the world indigenous peoples' human rights remain outside of specifically designated policy aims or legal safeguards. Not only is the cultural property of indigenous peoples looted far too often through illegal means, but it is also appropriated through legal avenues permitted by states..$^{75}$ Many states throughout the world also continue to deny indigenous peoples the right to have their cultural property returned to their rightful communities. ${ }^{76}$ Indigenous peoples and their property play an incredibly important role in enriching the traditions, history and heritage of humankind - meaning their rights need to be formally protected. What is essential in tackling this problem is to develop new regional legal instruments that take into account the specific needs of these communities. At the international level there are a number of legal standards that focus on indigenous rights. ${ }^{77}$ However, there is only one binding instrument that specifically provides for the protection of rights of indigenous peoples: the International Labour Organisation Indigenous and Tribal Peoples Convention, ${ }^{78}$ which has only one provision (Article 4, para. 1) that refers to the property of these groups, and only binds twenty-two state parties - of which three are EU Member States. ${ }^{79}$ With respect to customary standards under international law, ${ }^{80}$ there

73 A. Edwards, Global forced displacement hits record high, "UNHCR", 20 June 2016, http://www.unhcr. org/uk/news/latest/2016/6/5763b65a4/global-forced-displacement-hits-record-high.html [accessed: 21.11.2016].

74 See M. Åhren, Indigenous Peoples' Status in the International Legal System, Oxford University Press, Oxford 2016, in particular pp. 90-96.

75 See N. Mezey, The Paradoxes of Cultural Property, “Columbia Law Review” 2007, Vol. 107, p. 2004.

76 F. Lenzerini (ed.), Reparations for Indigenous Peoples, Oxford University Press, Oxford 2009, in particular F. Francioni, Reparation for Indigenous Peoples: Is International Law Ready to Ensure Redress for Historical Injustices, p. 27; F. Lenzerini, The Trail of Broken Dreams: The Status of Indigenous Peoples in International Law, p. 73; A.F. Vrdoljak, Reparations for Cultural Loss, p. 197.

77 International Labour Organisation Convention no 169 Concerning Indigenous and Tribal Peoples in Independent Countries, 27 June 1989, 1650 UNTS 383; United Nations Declaration on the Rights of Indigenous Peoples, GA Res. 61/295, UN Doc. A/RES/61/295 (2 October 2007).

78 Ibidem.

79 See S. Wiessner, F. Lenzerini, Rights of Indigenous Peoples, International Law Association, Sofia Conference 2012, p. 10. 
are numerous rules, but enforcing them remains a major hurdle towards advancement in this area. ${ }^{81}$ It is true that on a policy level the development of international human rights law has been a beneficial step with respect to furthering the rights of indigenous peoples around the world, ${ }^{82}$ but in order to enforce such rights the framework frequently requires linkage to other rights, such as property rights, in order to gain traction for the purposes of litigation. ${ }^{83}$ This is similar to the advancement of business and human rights through developments such as the UN Guiding Principles on Business and Human Rights ${ }^{84}$ yet at present the most tangible way to legally respond to human rights abuses committed by corporations is to pursue litigation under domestic law mechanisms..$^{85}$ It is in this respect that regional mechanisms can become more authoritative than their similar international counterparts, because they have the capability of being able to be enforced in regional courts, where international rules are dependent on the consent of states and limited by domestic law implementation and interpretation. ${ }^{86}$ The OAS's legal provisions for protecting cultural property through trade restrictions transcend the state-centric approach to regional law-making as regards the protection of cultural property, by allowing the rights and interests of impacted non-state actors to be taken into consideration, and then appropriately addressed. ${ }^{87}$ Specificity is crucial, and this is an area where both the EU and AU can learn from the OAS. ${ }^{88}$ Indeed, rich and diverse cultures exist throughout Europe and Africa that do not stem from states as entities under international law, but from the people and communities within them.

\footnotetext{
81 Ibidem, p. 20.

82 K. Engle, On Fragile Architecture: The UN Declaration on the Rights of Indigenous Peoples in the Context of Human Rights, "European Journal of International Law" 2011, Vol. 22, p. 141.

83 J. Webber, The Public-Law Dimension of Indigenous Property Rights, in: N. Bankes, T. Koivurova (eds.), The Proposed Nordic Saami Convention: National and International Dimensions of Indigenous Property Rights, Hart, Oxford 2013, p. 79, pp. 85-87; C. Baldwin, C. Morel, Using the United Nations Declaration on the Rights of Indigenous Peoples in Litigation, in: S. Allen, A. Xanthaki (eds.), Reflections on the United Nations Declaration on
} the Rights of Indigenous Peoples, Hart, Oxford 2011, p. 121.

84 Guiding Principles on Business and Human Rights, OHCHR, United Nations, New York - Geneva 2011.

85 B. Stephens, Corporate Liability: Enforcing Human Rights through Domestic Litigation, "International and Comparative Law Review" 2001, Vol. 24, p. 401.

86 For the key limitations on enforcing international legal instruments, and the significantly more difficult task of enforcing customary international law, see J.L. Goldsmith, E.A. Posner, The Limits of International Law, Oxford University Press, Oxford 2005.

87 For additional information regarding indigenous cultural heritage and trade under international law, see C.B. Graber, K. Kuprecht, J.C. Lai (eds.), International Trade in Indigenous Cultural Heritage: Legal and Policy Issues, Edward Elgar, Cheltenham 2012.

88 This is not to say that the framework of the OAS is perfect. In 1999 the Inter-American Institute of Human Rights stated that the "effectiveness of the Inter-American system in protecting economic, social and cultural rights has been practically nil" (J.L. Cavallaro, E.J. Schaffer, Less as More: Rethinking Supranational Litigation of Economic and Social Rights in the Americas, "Hastings Law Journal" 2004, Vol. 56, p. 217, p. 226). But the OAS framework has progressed considerably since 1999 . For additional commentary on this point, see K. Hausler, op. cit., p. 222, pp. 249-251. 
This calls for the protection of cultural property to be dealt with in a manner that, at the very least, acknowledges the rights and values of indigenous peoples and communities, ideally in the form of a binding regional instrument.

In order for an international system of cultural property protection to effectively function, there is a need for import restrictions in the state where such property is circulated in the market. Equally important, is the need for export controls in what is termed the "source state" of the property. This principle of reciprocity is key for the development of an international system of cultural property protection that functions effectively in practice. Prott and O'Keefe consider that restrictions on transfer and export applied by the source state are not always observed once cultural property has been transacted in another state, yet recognising and enforcing such restrictions through comity and reciprocity is crucial - especially with respect to clearly identifiable cultural property. ${ }^{89}$ In this regard, capacity-building within states' legal systems is key to ensuring that reciprocity can be delivered and maintained. Acknowledging such theoretical concepts is important, but becomes less helpful when such ideals drift further away from being tangibly applied in practice. This is where regional organisations can play their part in assisting states in the development and implementation of legislation at the domestic level that allows for reciprocal cultural property protection across national borders. Thus, in terms of ensuring that the concept of reciprocity is respected and enshrined in law, the EU's external work in states around the world serves as a stark illustration of what other global organisations could do to help solve cross-border concerns in this area. ${ }^{90}$

The final noteworthy concept on this issue is the outward-looking approach of organisations in protecting cultural property. In this regard the EU's work, through its external action, is highly commendable. Its assistance in protecting, for example, Iraq and Syria's cultural property sets a benchmark for other international actors to follow. ${ }^{91}$ African states such as Mali have also highlighted the benefit of collaboration in preventing illegal trade in cultural goods. However, the AU needs to develop its internal regulation of trade in cultural property before setting standards to address external action. The OAS, through its treaty-making, has solidified Member States in collaborating not only with one-another, but also with states located elsewhere in the world. ${ }^{92}$ In this respect, the EU benefits greatly from its

89 L.V. Prott, P.J. O'Keefe, Law and the Cultural Heritage, Vol. 3: Movement, Butterworths, London 1990, p. 641.

90 M. Telo, F. Ponjaert, The EU's Foreign Policy: What Kind of Power and Diplomatic Action? Routledge, London 2016.

91 Council conclusions on the EU Regional Strategy for Syria and Iraq as well as the Da'esh threat, EU Council, (23 May 2016) 9105/16.

92 M. Davies, Realising Rights: How Regional Organisations Socialise Human Rights, Routledge, London 2014, pp. 88-92. 
strong economies, ${ }^{93}$ as it has great resources to draw from when financing and implementing actions outside of the EU. This demonstrates that the financial burden that comes with assisting other entities outside one's own compartmentalised regime should not be avoided. In the context of cultural heritage protection, such conduct brings stability to all individuals, communities, and states through the enjoyment of a more progressive international environment.

\section{Conclusions}

It is evident that there are distinct differences between the EU, OAS and AU frameworks in terms of protecting cultural property through trade restrictions and sanctions. It is hard to say "which one is better", because all three organisations have different hurdles to overcome and are limited in capacity to varying degrees and, most notably, have dissimilar legal competences. The EU, owing to its developed framework, legislative powers and significant resources to draw from, is currently tackling the illicit trade in cultural property through trade restrictions and sanctions in the most tangible manner. If the effectiveness of each respective system is to be comprehensively evaluated, further comparative empirical research needs to be conducted in order to ascertain how successful each organisation has been in implementing its legal practice and policy objectives on this issue.

What can be taken from the above analysis are three overarching positives emanating from each regional body. Firstly, the EU's outward-looking approach to the protection of cultural property is an initiative that should be mirrored by other entities and states. Its law and policy aimed at protecting cultural property from illicit trade practices extends well beyond the geographical location of the EU Member States, meaning cultural property which forms part of the world's common heritage can be protected through concrete legal mechanisms. As with the European human rights framework, the EU offers more legal teeth to dig into the often meaty problems attached to globalised conduct, when compared to other regional - and international - structures. Secondly, the OAS has shown that the value of cultural property extends well beyond states. Protecting cultural property from illegal trade in various markets, whilst ensuring that the rights of indigenous peoples are respected, is a progressive component of OAS regional law that should be examined further by other entities. Lastly, although both the law and policy on protecting cultural property from illegal trade is minimal within the framework of the $\mathrm{AU}$, African states have shown a willingness to collaborate with external actors in the absence of a developed regional framework. Thus, through its Member States, the AU possesses great potential for improving the legal protections for cul-

93 C. Jones, A. Thomson, Eurozone GDP returns to pre-crisis levels, "The Financial Times", 29 April 2016, http://www.ft.com/cms/s/0/33f7a11c-0dd1-11e6-b41f-0beb7e589515.html\#axzz4H1F4lfTc [accessed: 21.11.2016]. 


\section{VARIA}

Richard Mackenzie-Gray Scott

tural property and advancing its policy to similar levels as those of the OAS and EU. If these three constructive elements can be secured and improved upon, then the illegal trade of cultural property throughout the world can be seriously combated through regulated trade practices based on solidarity.

\section{References}

African Charter on Human and Peoples' Rights, 27 June 1981, 1520 UNTS 217.

Åhren M., Indigenous Peoples' Status in the International Legal System, Oxford University Press, Oxford 2016.

Akinade O.A., Illicit Traffic in Cultural Property in Nigeria: Aftermaths and Antidotes, "African Study Monographs" 1999, Vol. 20.

Amineddoleh L.A., Cultural Heritage Vandalism and Looting: The Role of Terrorist Organizations, Public Institutions and Private Collectors, "Santander Art and Culture Law Review" 2015, Vol. 2.

Antiquities Law passed under Decree, Law No. 222 of 26 October 1963, http://portal. unesco.org/culture/fr/files/30606/11438206173Antiquities_Law.pdf/Antiquities\%2BLaw.pdf [accessed: 28.11.2016].

Baker A., Anjar M., Syria's Looted Past: How Ancient Artifacts Are Being Traded for Guns, "Time Magazine", 12 September 2012, http://world.time.com/2012/09/12/syrias-looted-past-how-ancient-artifacts-are-being-traded-for-guns/\#ixzz26ujLHJ8C [accessed: 21.11.2016].

Baldwin C., Morel C., Using the United Nations Declaration on the Rights of Indigenous Peoples in Litigation, in: S. Allen, A. Xanthaki (eds.), Reflections on the United Nations Declaration on the Rights of Indigenous Peoples, Hart, Oxford 2011.

Beqiraj J., Indigenous Peoples' Cultural Identity under EU Law and the ECHR: A Non-trade Interest or a Human Right?, in: F. Ippolito, S.I. Sanchez (eds.), Protecting Vulnerable Groups: The European Human Rights Framework, Hart, Oxford 2015.

Blake J., International Cultural Heritage Law, Oxford University Press, Oxford 2015.

Borchardt K.-D., The ABC of European Union Law, Publications Office of the European Union, Luxembourg 2010, https://eeas.europa.eu/sites/eeas/files/15102015eu_law.pdf [accessed: 21.11.2016].

Borgestede G., Cultural Property, the Palermo Convention, and Transnational Organized Crime, "International Journal of Cultural Property" 2014, Vol. 21.

Cavallaro J.L., Schaffer E.J., Less as More: Rethinking Supranational Litigation of Economic and Social Rights in the Americas, "Hastings Law Journal" 2004, Vol. 56.

Chamberlain K., Hausler K., United Kingdom, in: J.A.R. Nafziger, R.K. Paterson (eds.), Handbook on the Law of Cultural Heritage and International Trade, Edward Elgar, Chelthenham UK - Northampton MA USA 2014.

Charter for African Cultural Renaissance, adopted by the Sixth Ordinary Session of the Assembly, held in Khartoum, Sudan, 24 January 2006.

Commission Implementing Decision on 2013 Special Measure for the Syrian population and host communities in Jordan, C 6795, European Commission, Brussels, 10 October 2013, http://ec.europa.eu/enlargement/neighbourhood/pdf/key-documents/syr- 
ia-jordan_sm_2013_merged-financing-decision-and-action-fiches_en.pdf [accessed: 21.11.2016].

Convention on the Protection of the Archaeological, Historical, and Artistic Heritage of the American Nations (Convention of San Salvador) 16 June 1976, UNEP/GC.15/Int.2 p. 150.

Cornu M., France, in: J.A.R. Nafziger, R.K. Paterson (eds.), Handbook on the Law of Cultural Heritage and International Trade, Edward Elgar, Chelthenham UK - Northampton MA USA 2014.

Cornu M., Recasting restitution: interactions between EU and international law, "Uniform Law Review" 2015, Vol. 20.

Council conclusions on the EU Regional Strategy for Syria and Iraq as well as the Da'esh threat, EU Council, (23 May 2016) 9105/16.

Council Directive 93/7/EEC of 15 March 1993 on the return of cultural objects unlawfully removed from the territory of a Member State, OJ L 74, 27.03.1993, p. 74.

Council Framework Decision 2001/500/JHA of 26 June 2001 on money laundering, the identification, tracing, freezing, seizing and confiscation of instrumentalities and the proceeds of crime, OJ L 182, 5.07.2001, p. 1.

Council Regulation (EC) No. 1210/2003 of 7 July 2003 concerning certain specific restrictions on economic and financial relations with Iraq and repealing Regulation (EC) No. 2465/96, OJ L 169, 8.07.2003, p. 6.

Council Regulation (EEC) No. 3911/92 of 9 December 1992 on the export of cultural goods, OJ L 395, 31.12.1992, p. 1.

Council Regulation (EU) No. 36/2012 of 18 January 2012 concerning restrictive measures in view of the situation in Syria and repealing Regulation (EU) No. 442/2011, OJ L 16, 19.01.2012, p. 1.

Council Regulation (EU) No. 1332/2013 of 13 December 2013 amending Regulation (EU) No. 36/2012 concerning restrictive measures in view of the situation in Syria, OJ L $335,14.12 .2013$, p. 3.

Craig P., Burca G. de, EU Law: Text, Cases, and Materials, $6^{\text {th }}$ edn. Oxford University Press, Oxford 2015.

Cultural Property Implementation Act (CPIA) 19 USC, (1983), Publ. L. No. 97-466, 96 Stat. 2329 , at 19 USC para. 2601-2613 (2006).

Cultural Property Import and Export Act, R.S.C. 1985, c. C-51.

Davies M., Realising Rights: How Regional Organisations Socialise Human Rights, Routledge, London 2014.

Directive 2014/60/EU of the European Parliament and of the Council of 15 May 2014 on the return of cultural objects unlawfully removed from the territory of a Member State and amending Regulation (EU) No. 1024/2012 [Recast], OJ L 159, 28.05.2014, p. 1.

Draft Declaration on the Rights of Indigenous Peoples, IACHR, 26 February 1997, 133 ${ }^{\text {rd }}$ session, 95 ${ }^{\text {th }}$ Regular Session.

Edwards A., Global forced displacement hits record high, "UNHCR", 20 June 2016, http:// www.unhcr.org/uk/news/latest/2016/6/5763b65a4/global-forced-displacementhits-record-high.html [accessed: 21.11.2016].

Engle K., On Fragile Architecture: The UN Declaration on the Rights of Indigenous Peoples in the Context of Human Rights, "European Journal of International Law" 2011, Vol. 22. 


\section{VARIA}

Richard Mackenzie-Gray Scott

European Convention on Mutual Assistance in Criminal Matters, 20 April 1959, 472 UNTS 185.

First Additional Protocol to the European Convention on Mutual Assistance in Criminal Matters, 13 March 1978, ETS No. 099.

Francioni F., Reparation for Indigenous Peoples: Is International Law Ready to Ensure Redress for Historical Injustices, in: F. Lenzeri (ed.), Reparations for Indigenous Peoples, Oxford University Press, Oxford 2009.

Franco M., A guide to the export and import of cultural goods between Russia and the European Union, "European Communities", June 2007, https://eeas.europa.eu/delegations/russia/documents/eu_russia/moving_art_07_en.pdf [accessed: 21.11.2016].

Frigo M., Italy, in: J.A.R. Nafziger, R.K. Paterson (eds.), Handbook on the Law of Cultural Heritage and International Trade, Edward Elgar, Chelthenham UK - Northampton MA USA 2014.

Goldsmith J.L., Posner E.A., The Limits of International Law, Oxford University Press, Oxford 2005.

Graber C.B., Kuprecht K., Lai J.C. (eds.), International Trade in Indigenous Cultural Heritage: Legal and Policy Issues, Edward Elgar, Cheltenham 2012.

Guiding Principles on Business and Human Rights, OHCHR, United Nations, New York - Geneva 2011.

Hausler K., Collective Cultural Rights in the Inter-American Human Rights System, in: A. Jakubowski (ed.), Cultural Rights as Collective Rights: An International Law Perspective, Brill-Nijhoff, Leiden - Boston 2016.

http://caribheritage.org/project [accessed: 21.11.2016].

http://www.oas.org/juridico/english/sigs/c-16.html [accessed: 21.11.2016].

http://www.unesco.org/eri/la/convention.asp?KO=13039\&language=E\&order=alpha [accessed: 21.11.2016].

ICOM, Red List: Niger Valley (Mali): http://archives.icom.museum/redlist/afrique/english/ page04.htm [accessed: 21.11.2016].

International Labour Organisation Convention no 169 Concerning Indigenous and Tribal Peoples in Independent Countries, 27 June 1989, 1650 UNTS 383.

ISIL and Antiquities Trafficking, "FBI News", 26 August 2015, https://www.fbi.gov/news/stories/2015/august/isil-and-antiquities-trafficking [accessed: 21.11.2016].

Jones C., Thomson A., Eurozone GDP returns to pre-crisis levels, "The Financial Times", 29 April 2016, http://www.ft.com/cms/s/0/33f7a11c-0dd1-11e6-b41f-Obeb7e589515.htmI\#axzz4H1F4IfTc [accessed: 21.11.2016].

Lenzerini F., The Trail of Broken Dreams: The Status of Indigenous Peoples in International Law, in: F. Lenzerini (ed.), Reparations for Indigenous Peoples, Oxford University Press, Oxford 2009.

Littoz-Monnet A., The European Union and culture: Between Economic Regulation and European Cultural Policy, Manchester University Press, Manchester 2013.

Lixinski L., Intangible Cultural Heritage in International Law, Oxford University Press, Oxford 2013.

Looting, the subsistence digging economy in Mali; and stemming the flow of looted antiquities from Mali to the USA, "Conflict Antiquities", 3 April 2012, https://conflictantiquities.wordpress.com/2012/04/03/mali-looting-export-usa-import/ [accessed: 21.11.2016]. 
Mezey N., The Paradoxes of Cultural Property, "Columbia Law Review” 2007, Vol. 107.

Moustaira E.N., Greece, in: J.A.R. Nafziger, R.K. Paterson (eds.), Handbook on the Law of Cultural Heritage and International Trade, Edward Elgar, Chelthenham UK - Northampton MA USA 2014.

National Stolen Property Act (NSPA) 18 USC paras. 2314-2315.

Native American Graves Protection and Repatriation Act (NAGPRA), 25 USC paras. 3301.

Nigeria's National Commission for Museums and Monuments, Decree No. 77, 28 September 1979, https://committeeforculturalpolicy.org/wp-content/uploads/2014/06/Decree-n\%C2\%B0-77.pdf [accessed: 28.11.2016].

Obradovic D., Lavranos N. (eds.), Interface Between EU Law and National Law: Proceedings of the Annual Colloquium of the G.K. Van Hogendorp Centre for European Constitutional Studies, Europa Law Publishing, Groningen 2007.

Parry W., Ancient Statues Smuggled from Nigeria Being Returned Home, "NBC News", 26 July 2012, http://www.nbcnews.com/id/48346178/ns/technology_and_science-science/t/ancient-statues-smuggled-nigeria-being-returned-home/\#.VzsQ1PkrKUk [accessed: 21.11.2016].

Peers S., Guide to EU decision-making and justice and home affairs after the Treaty of Lisbon, "Statewatch", December 2010, http://www.statewatch.org/analyses/no-115-lisbon-treaty-decision-making.pdf [accessed: 21.11.2016].

Prott L.V., O'Keefe P.J., Law and the Cultural Heritage, Vol. 3: Movement, Butterworths, London 1990.

Recommendation 1651 (2004) on Ending the Plundering on African cultural objects of the Parlamentary Assembly of the Council of Europe: https://assembly.coe.int/nw/xml/ XRef/Xref-XML2HTML-en.asp?fileid=17196\&lang=en [accessed: 21.11.2016].

Review of the Balance of Competences between the United Kingdom and the European Union: Culture, Tourism and Sport, Foreign and Commonwealth Office, "HM Government", February 2014, https://www.gov.uk/government/uploads/system/uploads/attachment_data/file/279456/2901485_BoC_CultureTourismSport_acc.pdf [accessed: 21.11.2016].

Second Additional Protocol to the European Convention on Mutual Assistance in Criminal Matters, 8 November 2001, ETS No. 182.

Shyllon F., The Nigerian and African Experience on Looting and Trafficking in Cultural Objects, in: B.T. Hoffman (ed.), Art and Cultural Heritage: Law Policy and Practice, Cambridge University Press, Cambridge 2006.

Shyllon F., The Recovery of Cultural Objects by African states through the UNESCO and UNIDROIT Conventions and the Role of Arbitration, "Uniform Law Review" 2000, Vol. 5.

Shylon F., Négri V., Schneider M., The Role of National and International Legal Instruments in the Protection of African Cultural Goods, "Report prepared for the second Pan-African Cultural Congress: Inventory, Protection and Promotion of African Cultural Goods", 5-7 October 2009, http://portal.unesco.org/en/files/48670/13173105361role_of_national_and_intl_leg_instrs.pdf/role\%2Bof\%2Bnational\%2Band\%2Bintl\%2Bleg\%2Binstrs.pdf [accessed: 21.11.2016].

Siehr K., Germany, in: J.A.R. Nafziger, R.K. Paterson (eds.), Handbook on the Law of Cultural Heritage and International Trade, Edward Elgar, Chelthenham UK - Northampton MA USA 2014. 


\section{VARIA}

Richard Mackenzie-Gray Scott

Stephens B., Corporate Liability: Enforcing Human Rights through Domestic Litigation, "International and Comparative Law Review" 2001, Vol. 24.

Strother G., Resolving Cultural Property Disputes in the Shadow of the Law, "Harvard Negotiation Law Review" 2014, Vol. 19.

Study on preventing and fighting illicit trafficking in cultural goods in the European Union, CECOJI-CNRS - UMR 6224, Contract No. Home/2009/ISEC/PR/019-A2, Final Report - October 2011, http://ec.europa.eu/home-affairs/doc_centre/crime/docs/Report\%20Trafficking\%20in\%20cultural\%20goods\%20EN.pdf [accessed: 21.11.2016].

Supranational Decision-Making Procedures, EU Parliament, "Fact Sheets on the European Union", 2016, http://www.europarl.europa.eu/ftu/pdf/en/FTU_1.4.1.pdf [accessed: 21.11.2016].

Telo M., Ponjaert F., The EU's Foreign Policy: What Kind of Power and Diplomatic Action?, Routledge, London 2016.

Treasure Act, 1996 (consolidated version), http://www.legislation.gov.uk/ukpga/1996/24/ contents [accessed: 28.11.2018].

Treaty Establishing the European Community (consolidated version), OJ C 325, 24.12.2002, p. 33.

Treaty on the Functioning of the European Union (consolidated version), OJ C 326, 26.10.2012, p. 47.

UNESCO Convention on the Means of Prohibiting and Preventing the Illicit Import, Export and Transfer of Ownership of Cultural Property, 14 November 1970, 823 UNTS 231.

United Nations Convention against Transnational Organized Crime, 15 November 2000, 2237 UNTS 319

United Nations Declaration on the Rights of Indigenous Peoples, GA Res. 61/295, UN Doc. A/RES/61/295 (2 October 2007).

United Nations Security Council Resolution No. 2199 (12 February 2015) UN Doc S/ $\mathrm{RES} / 2199$.

Vadi V., Witte B. De, Culture and International Economic Law, Routledge, London 2015.

Vrdoljak A.F., Reparations for Cultural Loss, in: F. Lenzeri (ed.), Reparations for Indigenous Peoples, Oxford University Press, Oxford 2009.

Wantuch-Thole M., Cultural Property in Cross-Border Litigation, De Gruyter, Berlin 2015.

Webber J., The Public-Law Dimension of Indigenous Property Rights, in: N. Bankes, T. Koivurova (eds.), The Proposed Nordic Saami Convention: National and International Dimensions of Indigenous Property Rights, Hart, Oxford 2013.

Wiessner S., Lenzerini F., Rights of Indigenous Peoples, International Law Association, Sofia Conference 2012.

Working Document of the Commission of May 1998 on support for indigenous peoples in the development co-operation of the Community and the Member States, https://eeas. europa.eu/human_rights/ip/docs/working_doc_98_en.pdf [accessed: 21.11.2016]. 